\title{
Assessing Bias: The Qualitative in the Quantitative, Darfuri War Fatalities and the Morality of War*
}

\author{
Stephen Reyna \\ Humanitarian and Conflict Response Institute University of Manchester \& Max Planck Institute of Social \\ Anthropology \\ Email: reyna@eth.mpg.de \\ Received February $4^{\text {th }}, 2$ 2011; revised March 19 $9^{\text {th }}, 2011$; accepted April 22 ${ }^{\text {nd }}, 2011$.
}

\begin{abstract}
This paper formulates a strategy for assessing bias, and applies it to quantitative assessments of the disaster of war in Darfur [Sudan]. In so doing it argues for qualitative investigations of quantitative analyses. The strategy examines epistemic and political regimes with the goal of revealing the sources, the directions, and the forces of bias. Examples of bias are discussed to illustrate the strategy including, among others, the draw-a-person IQ test, questions about how old you are or whether you can bear children in Chad, and the US army's Human Terrain System. Considerable attention is paid to US governmental biasing of its claims of war fatalities and genocide in Darfur. This biasing is shown to involve cherry picking, symbolic violence, and high-channel regimes of bias. It is shown how the bias assessment strategy may be of use in evaluating moral claims.
\end{abstract}

Keywords: Bias Assessment, Qualitative/Quantitative Analyses, US Government Claims of Genocide In Darfur, Moral Judgment

\section{Introduction}

Darfur in the Sudan experienced the reoccurrence of grim warfare in 2003, with the onset of paramilitary operations against government targets. Khartoum authorities insisted that there were on the order of 10,000 civilian deaths in Darfur between 2003 and 2008 (MSNBC, 2008). Most Western mass media put the figure at over 300,000 deaths. One NGO, the Coalition for International Justice, put it at over 400,000 (See GAO 2006 for different estimates). What is striking about these assessments is how widely disparate they are, provoking the question of why. I believe it is due to bias.

This article may leave some a bit disappointed. They come to it hoping to discover how many have really been killed in Darfur, and some idea as to the best assessment procedures for discovering such statistics. They will not get this knowledge. Rather my position will be that prevailing political and epistemic conditions are such that quantitative estimates of matters like mortality in conflict, or in other sorts of humanitarian disasters, are likely to be profoundly biased. This means that strategies for investigating the sources of quantitative assessments' bias are equally as important as the quantitative techniques themselves. Further, I shall claim that a quantitative assessment's validity will depend, in good measure, upon qualitative investigations. The paper thus has two labors. On the one hand, it argues for integration of qualitative with quantitative researches, thereby elucidating the qualitative in the quantitative. On the other, it advocates a strategy for the study of bias in social and cultural realms of quantitative assessment, in part by considering the disasters of war in Darfur. Argumentation proceeds by discussing the ancient debate between the partisans of qualitative versus quantitative methodologies as well as introducing a way of evaluating the bias of quan-

*This paper was original presented at the Humanitarian and Conflict Response Institute's seminar 'Assessing Humanitarianism: Disaster and Data Dissemination’. University of Manchester, Manchester, UK, February 26, 2010. titative assessments; then it proceeds to consider sources of epistemic bias, sources of political bias, and finally a case history of political bias in Darfur. The conclusion shows what such bias analysis can mean for judgment of morality.

\section{Assessing Reality and Its Biases}

Qualitative and quantitative ways of assessing reality have emerged, have tended to be judged as dueling opposites, and have spawned roistering brawls over which is the better way of knowing. Since Galileo Galilei's success in developing a mathematics of uniformly accelerated objects in the early $17^{\text {th }}$ century there has been a growing belief among intellectual elites that the more rigorous way to know things is quantitatively (Porter, 1996). Certain folk, usually in the humanities, have defended qualitative analyses, but such pleading has not impeded the expansion of quantitative techniques into the analysis of everincreasing domains of reality. Let us arrive at a preliminary understanding of the qualitative and the quantitative.

There is a tendency to simplify and to reduce the former to studies whose analyzes are based upon words and the latter to those based upon numbers. This oversimplifies. The approach I take-reflecting discussions in Becker (1996), Creswell (2003) and Kuhn (1961) — considers that there are different types of information about reality. Quantitative information is that relating to, or expressible in, terms of quantities of reality. It is the how much of being. Thus, mortality assessments that so many died are examples of quantitative data. Qualitative information is that relating to, or expressible in, terms of the qualities of reality. Of course, this provokes debate over the nature of quality; a spat that ranges from John Locke's classic (1690) distinction between primary qualities (like extension and solidity) and secondary qualities (such as color and sound) to A.J. Ayer's belief in qualia as 'sensory patterns' (1968). For our 
purposes quality is the distinguishing features of sensory patterns of being. It is the what is of phenomena, which make some chunk of being what it is. Qualitative information relevant to persons concerns a particular type of distinguishing features: the experiences of, and the meaning given to, to reality. A distinguishing feature of mortality is that people have ceased to be alive, which requires consideration of what is meant by life. The position argued in this text is that the qualitative and quantitative are not opposing ways of knowing one premodern and on the wane, the other modern and on the rise but complementary components in any inquiry in which rigorous knowledge is craved. One of these realms is that of humanitarian disaster, where perhaps a key assessment is of numbers killed. Darfur until recently a backwater among backwaters came in the first years of the $21^{\text {st }}$ century to dominate headlines as a place of the monstrosities of war so great that some declared genocide; which is why this paper investigates Darfuri war fatalities and their bias. Let us turn to bias.

The word bias is derived from the medieval English game of bowls and referred to the actual roll of the ball on release from the clasp of some lord or lady. Sometimes the bowl would be directly at the pins. Other times it would slant in some angle away from them. 'Bias' as it is used in this discussion is knowledge with a particular slant; that is, a certain quantity of knowledge pushed in a particular direction. The magnitude of the knowledge its generality may be little or large. For example, the magnitude of knowledge about war deaths is relatively smaller if it only refers only to deaths in Darfur between 2003 and 2008, and vaster if it refers to all those killed by war in all places at all times. The direction of the knowledge is the degree to which it is pushed along a particular path or, more quantitatively, along a certain measurement scale. The analysis of bias, is discovery of the reasons why a particular magnitude of knowledge exhibits a particular direction, or directions. Directions 'away from' or 'towards what' readers might ask? One answer to this question is away from or towards the approximate truth of some bit of knowledge. ${ }^{2}$ Of particular interest are circumstances where the same quantum of knowledge exhibits multiple directions. This is precisely the sort of bias reported for the Sudanese war mortality figures-where in both cases there is one bowler pushing the knowledge in a higher direction, and another pushing it in a lower direction.

Analysis of these biases is revelation of the sources of the pushing: discovery of the forces moving knowledge in particular directions, which is knowledge of who the bowlers are and how they do it. The bowlers are 'channels of information'-actors, social or individual that push a particular bias upon people. Epistemic and political information channels make epistemic and political forces moving knowledge in specific directions. By 'epistemic' forces I mean those that pertain to a regime of knowledge construction used by those making the knowledge. An 'epistemic regime' is any particular actor, or actors in knowledge-making institutions (comprising anything from forms of divination, to pop radio stations, to research institutes), using non-scientific and scientific procedures for constructing knowledge. By 'political' forces I mean those that pertain to groups, or collections of groups, ranging from families to states, with resources that can be utilized to oblige the

${ }^{2}$ I (2010) have argued, as have others, that one is on firmer epistemological ground if one seeks approximate truth rather than the truth. construction of knowledge favorable to the interests of those groups. 'Political regimes' are actors in governmental institutions exercising their resources to force construction of desired knowledge. What makes any regime a regime is that it concerns the actions of actors in a particular institution at a political time. So, for example, there were the different regimes of the Prime Ministers Disraeli and Gladstone in $19^{\text {th }}$ century England.

Directions can be forced and bias constructed either by the action of actors in epistemic regimes alone or by the action of actors in political regimes controlling the operation of epistemic regimes. Foucault might have called such actions the operation of regimes of truth (1980). I prefer to conceptualize them as 'regimes of bias', because what is at issue is not the construction of truth but of bias. Different regimes of bias can be distinguished in terms of strength of the force pushing a particular vector of bias. This strength can be imagined to increase with the number of information channels inclining actors to accept a particular bias. If for example there are only one or two radio stations asserting that Manchester United is the best football team in the world, the strength of the bias in favor of Manchester United is less than that if all radio stations, all television stations, all newspaper, and all off the internet make the same claim. Regimes of bias where only a few information channels push a bias will said to be 'low channel'. Those where a large number of information channels push a bias will be termed 'high channel'. In any strategy assessing bias, it seems entirely sensible to employ epistemic regimes most capable of establishing approximately true knowledge to establish the approximate truth of quanta of knowledge and, then, to establish the force of bias away from that truth. Attention turns to some sources bias in epistemic regimes.

\section{Epistemic Sources}

Epistemic bias can result from a number of sources. Three these imperfect techniques, cultural relativism, and emotive coloring are discussed in this section. Let us begin with imperfect techniques.

Flawed techniques: empirical data collection and analysis methods vary in their quality and can themselves be designed (normally inadvertently) to produce information exhibiting some bias. Consider for example, the Draw-a-Person Test. The test administrator asks the person being tested to draw somebody. A total of three pictures are drawn. The tester, then, analyzes fourteen different aspects of the drawings, such as specific body parts and clothing, for various criteria, including presence or absence, detail, and proportion. In all, there are 64 scoring items for each drawing. A separate standard score is recorded for each drawing, plus a total score for all three of them. The use of a nonverbal, nonthreatening play-task to evaluate intelligence is intended to eliminate possible sources of bias by reducing variables like primary language, verbal skills, communication disabilities, and sensitivity to working under pressure. When given to a sample of people of Islamic origin the average score on this test was in the order of 34 ! Why? The Draw-a-Person Test asks Muslims to draw the human form which is haram (forbidden). When given the test the Muslims politely drew some scribble and the test, using the procedures it had for scaling pictures, systematically gave them the lowest scores. Otherwise put, the Draw-a-Man test is sys- 
tematically biased to classify Islamic peoples as idiots.

There is a set of assessment techniques that are often utilized in disasters that are suspect for another set of reasons. These are Rapid Assessment Procedures (RAP) and Rapid Rural Appraisal (RRA) (Scrimshaw \& Gleason, 1992). They are survey methodologies that search for opinions and attitudes, behavior, and motivations of both the clients of disaster or development programs and also those who deliver services. Their questionnaires are normally generic, not specifically tailored for particular places. Sampling and administration procedures are designed to they can be performed quickly. The teams performing them normally come from somewhere else, work for a brief period (Days or weeks), and leave quickly. The teams are said to be 'parachuted in' and their research to be 'quick and dirty'. I have observed the use of such techniques for three decades, and believe they are, indeed, 'dirty'.

There are three key problems. The first has to do with the time allotted for the research. Usually this is too short. For example, I was once contacted to do a RRA concerning land tenure along the Chad/Cameroon oil pipeline. The pipeline is well over a 1000 kilometers. Questions of land tenure are notoriously difficult to gather information on because they deal with sensitive issues effecting peoples' welfare. I was to be allotted four weeks to conduct the survey. I was uncertain of whether I could travel the length of the pipeline in four weeks let alone conduct interviews. A second problem with RRAs is that the people administering them are often poorly trained. The combination of improperly trained persons plus inadequate time for them to do their jobs means that any knowledge gained tends to be biased in any number of directions, all away from the approximate truth. There is a third biasing factor with RRAs. They tend to afflicted by problems arising from cultural relativism. This, however, is basic problem and is considered in the next section.

Cultural relativity: cultural relativity is the recognition that different peoples have different systems of meaning (i.e., cultures) so that the meaning of things is relative to the culture they are in. For example, were I now to grab my male member, and agitate it rapidly against my left thigh, it would mean that I was either crazy, sexually depraved, or both. However, were we in the Amazon forest, and were we of a group called the Nambikwara, then Lévi-Strauss (1948) informs us that my fondling would indicate, 'Hello', and politely at that. The problem with cultural relativity is that if I do not know the culture in which I am posing questions, I do not know the meaning of what I am asking.

Cultural relativity can lead to bias because there can be a double set of meanings. The first meanings are those of the words in my culture and the second is the meaning they have in the culture of the persons I am asking questions. For example, the word 'African' in Western culture means more or less 'anybody from Africa'. However, the word 'African' means something quite different in current Darfuri culture. Generally it refers to landowning, peoples who emphasize farming and who had more centralized polities, such as the Fur or Masalit. Those who respond to the question, 'Nafara chenu' (What is your kind?), with 'Ana Arabiya' (I am an Arab) do not consider themselves African. They are Arabs, even through they may be neighbors living a few hundred feet from a Fur family. ${ }^{3}$ Now if I pose the question in Darfur, 'Are you an African' I am likely to find a hefty percentage of the population respond that they

${ }^{3} \mathrm{~A}$ useful discussion of the difference between 'Arab' and 'African' identities can be found in Penitsch (2010), De Waal (2009), and Mamdani (2009). are not African. This biases my knowledge of the Darfuri population to an under reporting of its fundamentally African nature. Let us say that I arrive at a quantitative estimate that $50 \%$ of the population is African. However, the reason it is case is because of the qualitative nature of the meaning of who is and who is not classified as African. This, then, is an example of the qualitative in the quantitative.

Another problem that can arise due to the ignoring of cultural relativity is that the interviewer may pose questions that in a particular culture are simply impossible to answer, for one of two reasons. The first of these is that the interviewer asks the question in a way that cannot be posed in a particular culture. For example, while conducting a demographic survey in Chad I asked, 'How old are you?', and found in a preliminary survey that I was getting a huge number of 'do not know' responses. Then I recalled that when people spoke of their age they did it in terms of the number of dry seasons they had lived through. So I changed the query and asked, 'How many dry seasons have you been through'? After which, the number of 'do not know' responses declined. A second reason that a question may be unanswerable is that it is culturally inappropriate. For example, once I studied a group of Chadian Arabs called the Abu Krider. They were a garrulous folk, often speaking frankly about matters about which I blanched. They were cattle-herders, and as the livestock component of their domestic economy was considerable, I sought to know how many animals they owned. When the question 'how many head of cattle do you own' was asked, my interlocutor would look at me in silent distress, as if I had asked the Queen whether she liked to crack a good fart. One does not query royalty about their flatulence, or Abu Krider about their treasure in cattle. Ignorance of the relativity of cultures can lead to a further epistemic source of bias. This is emotive coloring, discussed next.

Emotive coloring: emotive coloring explains why some questions are inappropriate in a particular culture. Certain questions provoke emotions that make answers to those questions either inaccurate or not possible. For example, my first research in Chad was among the Barma who exhibited low fertility, which was unusual because people in sub-Saharan Africans generally had a high fertility. I was concerned to explain this low fertility. So I would ask women, 'were they able to have children'? Perhaps, a callous question to pose of any woman, but little did I realize just how cruel it was to Barma women. Among the Barma, having children, many of them, was extremely desired. The proverb, 'A woman without children is like a tree without leaves', expressed this desire. Children were moral and practical valuables, the source of wellbeing. Barma culture strongly rewarded a woman with lots of children, and punished one without them. Just as there was something perverse and dead about a leafless tree, so there was something wicked and lifeless in a childless woman. Such people it was believed might become witches. So when I asked a woman if she could have children, it evoked deep emotion in her, traces of which I learned to recognize, and she invariably answered in the positive, of course she could have children. This meant that even though fully a fifth of Barma women appeared infertile, virtually all of them claimed to be fertile, even if they were ancient crones who everyone said had never had children. The data was biased by the emotional coloring given by the question. I very soon stopped asking the question as terribly unkind and unanswerable. Consider now political sources of bias. 


\section{Political Sources}

Political bias results from the exercise of force resources in the institutions of governmental regimes so that they have the power to drive assessments in various epistemic regimes along particular vectors. Sources of political bias may be direct or indirect. 'Direct' political bias occurs when governmental institutions themselves function as epistemic regimes that produce assessments with a particular vector. 'Indirect' political bias occurs when institutions in a governmental regime create their powers of bias by controlling epistemic regimes to actually construct the knowledge with a particular vector. Let us look at both indirect and direct sources of political bias.

Direct political biasing: direct political biasing occurs when institutions in the governmental regime are the institutions in the epistemic regime. There is a current militarization of direct political biasing. The militarization of data collection is part of an ongoing militarization of American intellectual life (Bacevich, 2006; Boggs, 2004) and is not a new phenomenon. Both Margaret Mead and Ruth Benedict, for example, conducted research for the military during World War II. Benedict's famous The Chrysanthemum and the Sword (1946) was a project of the US Office of War Information.

Recently, 2005 and 2006, the US military created an institution designed to conduct research in the midst of combat to boost its counterinsurgency capabilities. This is the Human Terrain System (HTS), a US Army program which incorporates social scientists into combat brigades to help tacticians in the field understand local cultures (Price, 2009). An HTS consists of five-person teams ('Human Terrain Teams', HTTs) assigned to brigade combat team headquarters. They include personnel from anthropology, sociology, political science, geography, regional studies, and linguistics. Currently HTTs are in Iraq and Afghanistan. They utilize a methodology called Human Terrain Mapping (HTM) that consists of an automated database and presentation tool for collecting, storing, and manipulating cultural data from numerous categories including key regional personalities, social structures, kin groupings, economics, public communications, agricultural production, and the like. In the $19^{\text {th }}$ century when the American army fought Native Americans, they used scouts for tips on how to do their killing. HTTs are the army's new scouts. The knowledge they construct is biased in favor of tips on how to kill the new natives in Iraq, Afghanistan, or wherever they might be.

There are any numbers of ways such militarization of data collection can bias assessments. Consider one concerning the US/Nato Campaign at Marjah in Afganistan [February-March 2010]. This region is the heartland of the Taliban, and has been so for a long time. The people are relatively prosperous. They cultivate poppies, and poppy production pays higher than any other form of agriculture in Afghanistan. Taliban governance resonates with local people who are Pashtin. The Taliban, for the most part are Pashtun, and govern respecting Pashtunwali, the Pashtun cultural code. While not all people in the region 'like' the Taliban, it is likely that most do. One US military source put this liking at 95\% (Martin, 2010). Prior to the onset of the campaign a survey was conducted to judge how positively the invading troops might be received. Whether the survey was conducted by an HTT is unclear, though likely. The survey found that the people about to be invaded looked positively upon the arrival of the Americans. Why? Put yourself in the place of a Marjah inhabitant. A team of researchers arrives, replete with armed guards. You know you are to be invaded and that their people will do it. You know they are capable of horrific violence. They ask you, ‘do you like them'? You probably don't. But you are terrified of what they will do to you if you say you hate their guts. So you respond positively, and the knowledge that the invaded are fond of their invaders is constructed. This bias is established by emotive coloring. The interviewer, associated with the extremely violent invader, strikes fear in the interviewees; the fear guides their answers. The percentage positive evaluation of American occupiers is a quantitative assessment. The discovery that emotion guides respondents' reasons for the positive assessment comes from qualitative explorations of the interviewees' subjectivities. This is another case of the qualitative in the quantitative. It is time to consider indirect political biasing.

Indirect political biasing: there are two important ways in which governmental regimes achieve powers over epistemic regimes and thereby bias knowledge produced by the latter. The first way involves the governmental regime regulating the resources that flow to the epistemic regime. Two sorts of resources flows are critical. The first is that of money. Money for research in the US comes largely from military and governmental funding agencies sources. The US military hands out $\$ 1.5$ billions per year in research money (Marcus, 2009) much of it to elite universities; for example, the Department of Defense gave over \$300 millions to Harvard University in 2002 (Turse, 2010). Who would doubt that actors in epistemic regimes receiving the wherewithal of their professional life from military, governmental regimes would bite the hand that feeds them? The two most important governmental funding agencies are the National Science Foundation and the National Institutes of Health. Both refrain from supporting Marxist projects. The vast majority of grant seekers are well aware that this is the case. Consequently, US governmental funding assures that there is a bias is against research with socialist interests. The second sort of resource flow to epistemic regimes is that of intellectual resources.

An 'intellectual resource' is a concept, or set or concepts, which stipulate how actors in some epistemic regime construct knowledge. For example, the US the Bureau of Labor Statistics (BLS) of the US Department of Labor defines unemployment. In fact, 'Persons are classified as unemployed if they do not have a job, have actively looked for work in the prior 4 weeks, and are currently available for work' (BLS 2010). This means that when some private epistemic regime, say the University of Michigan Institute for Social Research, calculates unemployment in America it does so on the basis of the BLS's definition of the concept. Through much of 2009 when it made such constructions it reported the US had an unemployment rate of $10.2 \%$. There is a problem, however, with the Bureau's conceptualization. It does not include as unemployed those who have no work and have stopped looking for work. When these persons are included in the sum of those without work, US unemployment in 2009 was about $17.5 \%$. This assessment is generally acknowledged to be approximately true. The BLS, thus, should be seen as an indirect political source of bias towards the under reporting of American joblessness.

A second way in which governmental regimes indirectly bias is by a practice called 'cherry picking'. 'Cherry picking' is the examining of a body of knowledge and picking that which one 
desires. A governmental regime's cherry picking is utilization of their resources to oblige acceptance of assessments arrived at by private epistemic regimes congenial to the governmental regime. Officials do this either by rejecting assessments not in their interests or affirming those in their interests. Avowing or disavowing is often done on the basis of non-empirical, nonlogical forms of argumentation. For example, the Bush II administration did not approve of a Lancet study's high assessment of excess deaths in Iraq. In order to disown it President Bush simply asserted: 'I don't consider it a credible report' (in Bennett-Jones, 2007). The President offered no warrant for his assessment. The British Ministry of Defense's chief scientific adviser said the survey's methods were 'close to best practice' and that the study's design was 'robust' (Ibid, 2010). Whether or not the Lancet study's findings are the approximate truth is not at issue here. What is pertinent is that the US President was cherry picking of the level of mortality in the Iraq war by rejecting one unfavorable to his interests, thereby biasing the war fatalities in a downward direction. I believe there has been US cherry picking of the higher assessment of mortality in the Darfuri conflict. This case is made next.

\section{The Biasing of Darfur Assessments of War Mortality}

'It is up to us, and our partners in the international community, to make a concerted and sustained effort to help bring lasting peace and stability to Sudan and avoid more of the conflict that has produced a vast sea of human misery and squandered the potential and security of a vital region of the world' (Hilary Clinton, US Secretary of State, Speaking on US Policy Towards Sudan, October 19, 2009 (Clinton, 2009)).

Secretary of State Hilary Clinton articulated US policy towards the Sudan in an October 2009 press briefing. ${ }^{4}$ She stated that the policy was to 'help bring lasting peace and stability' to the Sudan. If one scrutinizes what US policy actually does, instead of what officials claim it does, observation suggests that that this policy has been designed to bring war and instability to Sudan, and that one of the ways it has sought to do so is by cherry picking assessments of the fatalities in Darfur.

Significant when seeking understanding of US/Sudan relations is awareness that Sudan's position-close to the Arabian Peninsula and as a backdoor to Egypt-give it a geopolitical significance. Further, its Islamist orientation is disapproved of by both US missionaries, active in Southern Sudan, and the US government. Additionally, and perhaps most crucial, oil is running out in the world; the US is warring to control as much of the remaining oil as it can; the US has identified Africa as a major source of oil in the future (Reyna, 2009); and Sudan may actually hold Africa's greatest unexploited oil reserves (Hennig, 2007: p. 1). US and Chinese imperialisms are in competition

${ }^{4}$ Much discussion of the conflict in Darfur between 2003 and the present has been by American or Western scholars, journalists, and government officials A number of scholars-some conservative (Ferguson, 2004), some in the center (Bacevitch, 2002) and some on the left (Harvey, 2003; Reyna, 2005)believe that the US, with its Western allies, have embarked upon a 'new imperialism'. Thus, it is sensible to query whether certain Westerners framing the Darfur conflict are consciously, or unconsciously, part of this imperial project. It might be objected that the analysis in this section absolves the Sudanese government of responsibility for the Darfur conflict. The government of Omar al-Bashir bears a grave accountability for the disasters. However, this is not the topic of the present section. over Sudanese oil. Currently, Sudanese oil is controlled largely by the China National Petroleum Corporation (CNPC). Production occurs in southern Sudan, but there is a possibility of deposits to the northwest in southern Darfur. Beside the 1998 attacks on al-Ahifa, a Sudanese pharmaceutical company, during President Clinton's administration, there have been covert, indirect US global warring against Sudan that goes back to the 1980s. ${ }^{5}$

Let us consider first southern Sudan, which was, and is, non-Muslim and has resisted the northern Muslim domination since 1955. There have been two periods of war there-the First (1955-1972) and the Second (1983-2005) Sudanese Civil Wars. It is the later war that is of interest, for the US was largely indifferent to the Sudan during the former one. John Garang formed the Sudanese Peoples' Liberation Army (SPLA) in 1983 and began serious rebellion against the Khartoum government. The US provided a '... covert supply of arms to the SPLA....' (Hassan, 2009). Support for the south escalated when the Clinton administration, 'In 1996 ... decided to send over $\$ 20$ million of military equipment through the 'front-line' states of Ethiopia, Eritrea and Uganda to help the Sudanese opposition overthrow the Khartoum regime' (Hassan, 2009). It should be recognized that the US was largely fighting in the Sudan through its proxies, especially Uganda and Eritrea; though there appear to have been, '...several Operational DetachmentsAlpha teams (also called A-Teams) of the US army ... operating in support of the SPLA...' (Hassan, 2009). Thus, US military involvement in southern Sudan was largely covert and, with the exception of the 'A-Teams', largely indirect.

Julie Flint has remarked'... the war for oil was terrible' in the southern Sudan in the 1980s and 1990s (2009). Ahmed Hassan recounts one '....direct attempt' at this time ' ... to protect ... the U.S oil companies' that were still operating in the early 1990s. This involved '....Abdel Aziz Khalid, under the direct influence of Dr. Taisier...'. Abdel Aziz Khalid, originally from the Sudanese military, was the head of the Sudan Alliance Forces (SAF). This was a northern rebel political movement and militia formed in 1996 to oppose the Khartoum government. Dr Taisier M. Ali, formerly a historian at the University of Khartoum, was on the Command Council of the SAF. He maintained ties with the US at that time, largely though John Prendergast, Clinton Administration's Nation Security Council's director of African Affairs. During the incident Ahmed Hassan related, Taisier '...was leading a feverish campaign' to maintain '...the interests of the U.S oil companies' and which involved issuing'... warnings to all foreign companies involved in Sudan to pull out or their installations and personnel would be considered legitimate military targets' (Hassan, 2009). Let us be clear, the SPLA sought to destabilize the al-Bashir regime. US indirect global warring in support of the SPLA was part of the destabilization campaign. Destabilization of Sudan might shake the oil resources free from the Chinese.

Equally, in the early 2000s there is evidence that the US sought to further militarily destabilize the Khartoum government by exacerbating rebellion in Darfur. Here anti-Khartoum guerilla movements (the Sudanese Liberation Army, SLA; and Justice and Equality Movement, JEM) emerged, and in April 2003 be-

\footnotetext{
'The notion of' global warring' can be found in Reyna (2009) and refers to overt or covert, direct or indirect exercise of destructive force by the killing elites of an imperial state in a colony or neo-colony somewhere else on the globe.
} 
gan attacking government installations in el Fasher (Flint \& De Waal, 2005). Khartoum, militarily overextended due to the southern situation, responded by encouraging a nomad Arab militia, the janjawid to attack the SLA and JEM. One reason the Khartoum government may have been so eager to assert control in Darfur was the prospect of oil there. There had been rumors of oil since the 1990s. Flint reports, 'In April 2005, Energy Minister Awad al-Jaz grabbed headlines by announcing discovery of a giant oilfield in southern Darfur that he said was expected to produce 500,000 b/d within months. .... But announcements of success were premature and proved illusory...' (2009). The amount of oil in Darfur is unknown. Real, however, is its possibility in the minds of both the Khartoum government and American officials. The American military's hand in the fighting that ensued in Darfur is covert. However, 'It is ... well documented that the US through its closest African allies, helped train the SLA and JEM Darfuri rebels that initiated Khartoum's violent reaction...'(Hennig, 2007: p. 1). Information gathered during my fieldwork bears upon two aspects of this intervention. Firstly, the Israeli's have been involved in training of SLA members, some of whom were taken to Israel for this purpose. There is a SLA office in Israel. It is unlikely that the Israelis are operating without US collusion. Secondly, one account I have insists that US proxies' training of Darfuri militias occurred prior to their assaults on the Khartoum government's installations. It was these attacks that provoked the government to organize the janjawid counterattack; and it was the ferocity of this counter-offensive that led to the high war fatalities in Darfur.

It is at this point the US government cherry picking of Darfuri fatalities occurred. Consider the 'cherries' to be picked. There were, as indicated at the article's beginning, high and low estimates. In addition to the Sudanese government's low figure of 19,000, Eric Reeves, a Professor of English at Smith College, claimed in January 2005 that there had been in the order of 400,000 excess deaths. He further claimed that there were about 450,000 excess deaths by April 2006 (Reeves, 2006; Cherry, 2009). 'Excess deaths' are those above the normal mortality rate and are believed in the case of Darfur to be the result of violence as well as disease and malnutrition provoked by the violence of the warring. The Coalition for International Justice, in a study prepared by John Hagen, a Northwestern University sociologist, assessed the level of excess deaths at 400,000 in April 2005 (Hagen et al., 2005). The Center for Research in Epidemology of Disaster (CRED) of the Université Catholique de Louvain argued that there had been 118,142 excess deaths through June of 2005 (Guha-Sapir et al., 2005). The US State Department approximated that there had been between 63,000 and 146,000 excess deaths by 2005 (Department of State, 2005). Finally, the World Health Organization proposed that there were between 35,000 and 70,000 excess deaths for seven months in 2004 (Nabarro, 2004).

Let us investigate as best possible the approximate truth of the level of war fatalities. The General Accounting Office (GAO) of the US Congress performed an assessment of the assessment of Darfur war fatalities conducted by 12 experts in epidemiology, demography, statistics, and the Darfur crisis. It evaluated the five studies discussed above plus a sixth. The specialists reviewed the quality of source data; methods, including extrapolations and assumptions; researchers' objectivity; and transparency concerning study procedures. The reviewers obtained supplementary information from those who conducted the research when necessary. The GAO report's verdict was,

'Although none of the death estimates was consistently considered accurate or methodologically strong, the experts we consulted rated some of the estimates more highly than others. Overall, the experts expressed the highest level of confidence in CRED's estimates and slightly lower levels of confidence in State's and the WHO's estimates. They expressed the lowest level of confidence in the three estimates that report the highest number of deaths, citing multiple shortcomings, such as a reliance on unrealistic assumptions about populations' level of risk over periods of time'(GAO, 2006: p. 3).

What the preceding suggests is that no solid assessment of the excess deaths in the Darfur conflict exists, but that the higher estimates are not credible. Judgments made upon the level of war fatalities since the GAO support its findings (De Waal, 2007; Brauman, 2010). These, then, were the cherries that the US government could pick, with it recognized that the higher assessments had 'the lowest level of confidence'.

Of course, it was in the US interest to have Darfuri fatalities as high as possible because this delegitimized the Khartoum government, legitimating Western intervention, which intervention held the possibility of US gaining influence in Sudan -over, among other things, the oil. Starting in early 2004 the Bush II regime choose to report the highest estimates as the correct ones. This was cherry picking. On June 3, 2004, Andrew Natsios, Administrator of the USAID asserted that his agency had a study that predicted for the year 2004, 'Even in a best-case scenario, under optimal conditions, we could see as many as 320,000 people die' (Winter, 2004). Two weeks later, on June $15^{\text {th }}$, Roger Winter, another top USAID official, stated 'USAID analysis of potential mortality rates in Darfur suggests that 300,000 or more Darfurians are likely to perish by the ends of the year...' (Winter, 2004). What was the 'analysis' that formed the basis of Winter and his superior's assessments? It is not referenced in the text in which Winter discusses it. In fact the 'analysis' may not have been a proper research study. It seems to be a single chart inserted into Winter's text. The sources cited as being used to construct the chart are epidemiological studies in Bahr-i-Ghazal and Ethiopia in 1998 and 2000 (neither of which are in Darfur), a 2001 Save the Children doctor's report, and a 2004 FAO report on 'wasting' in Darfur. The validity of these sources is, unremarked. How they were utilized to construct the chart, unreported. Consequently, the truthfulness of the chart's information is unknown, which may explain why it was excluded from the GAO's assessment of the different studies of Darfur war fatalities. Nevertheless, Winter and Natsios by the middle of 2004 had plucked the cherry of Darfur war fatalities alternatives, and they had picked the higher estimate, the one with 'the lowest level of confidence'. Presumably emboldened by these figures, US Secretary of State, Colin Powell, declared on September $9^{\text {th }}$ that was the Khartoum government with their Janjawid allies were doing in Darfur was genocide (BBC 2004). Nine months later, June 2, 2005, Bush II, added his assessment. It was genocide (VandeHei, 2005). What was happening here?

One interpretation is that the US government was exercising symbolic violence against the Khartoum government and that this violence was part of a regime of bias operating against the Sudanese state. The notion of symbolic violence was formulated by Pierre Bourdieu (1989, 1991) who believed that power could be understood as different forms of 'capital'. One form of 
capital was what he termed 'symbolic', any type of power that derives from socially inculcated classification schemes of norms and values (e.g., prestige, honor, etc.). 'Symbolic violence' is the exercise of symbolic capital by a social or individual actor against some other actor. For example, a young Indian, Brahmin woman might bring home to her mother a man of lower caste with whom she is in love. Her mother is horrified and says the man is untouchable. The young woman has been enculturated into the caste system. She knows her mother is correct, that she cannot marry outside of her caste, and breaks off with the man. The mother's discourse informing the girl of her caste obligations is the exercise of symbolic violence. Turning to the Sudan case, it should be recognized that committing genocide puts a government in the 'untouchable' category in any current classification of state legitimacy. The US government claimed the Sudanese government practiced genocide in Darfur. In part it established this designation by cherry picking among assessments of Darfur mortality, choosing one that gave weight to claims of genocide. This classified the Khartoum regime as a moral monster. The classification of the Sudanese government as a moral monster was an act of symbolic violence with the power of delegitimating it.

At the same time the US government was exercising symbolic violence against the Sudan, numerous, humanitarian advocacy groups, like the Coalition for International Justice, began publicize as widely as possible the higher estimates of excess mortality and genocide. Important here was, and is, the Save Darfur Coalition, which describes itself as a 'faithbased, humanitarian, and human rights organization' (Save Darfur, 2010), and which, according to one source is, '...partially influenced by the agenda of right-wing groups associated with the Christian right and the pro-Isreali lobby in the US and Europe' (Hassan \& Salah 2009: p.156). Save Darfur was soon claiming that 300,000 excess deaths had occurred between 2003-2005, that this was genocide, and calling for intervention. ${ }^{6}$ Sectors of the US press, notably Nicholas D. Kristof in the New York Times, began to publicize the higher estimates. For example, Kristof claimed that there had been '...320,000 deaths this year (2004) (a best-case projection from the U.S. Agency for International Development)' (Kristof, 2004). Congress people-both Republican and Democrat-added their voices to the chorus. Equally some members of the African-American community, notably the Black Caucus in the US Congress, labeled the war in Darfur genocidal and called upon the US government to intervene (Salih \& Booker, 2004). The US Holocaust Museum in Washington and the Holocaust Museum in Houston Texas got into the fight against genocide in Darfur. Movie stars and directors-Mia Farrow, Angela Jolie, George Clooney, Steven Spielberg told fans that what was happening in Darfur was genocide.

The US government's classification of Sudan as a genocidal state, conjoined with the NGOs, the media, the Congress people, the influential African Americans, and the holocaust museums operated as what was termed at the beginning of the essay a high-channel regime of bias, one exercising symbolic violence categorizing the Khartoum regime as something beyond the

${ }^{6}$ There is a current of opinion that asserts NGOs like Save Darfur cried genocide as '.... a means of diverting the attention of the mainstream media from American atrocities in Iraq and Afghanistan and from Isreal's brutal oppression of the Palestinians...' (Hassan \& Salah, 2009: p. 156). It is indisputable that there were widespread claims of Sudanese government genocide in the Western press, and certainly these did in part shift attention away from US and Isreali brutalities. pale, like the Nazi's with their penchant for genocide. It seemed for a while in 2004 and 2005 in the US that wherever you turned all channels of information informed you of the monstrosities of Sudan's rogue state. This was a high channel regime of bias because multiple regimes of knowledge construction pushed peoples' perceptions of what was happening in Darfur away from the direction of what was the approximate truth of what was happening. Make no mistake about it, the warring of all the militaries - the janjawid, the SLA, the JEM, the Sudanese military, and even the covert hand of the US-was terrible. But the lower assessments of war fatalities, the US government's own GAO report judged, were the ones more likely to be true. Such assessments indicate grim combat but are inconsistent with genocide. ${ }^{7}$

Hilary Clinton stated that it is US policy to bring 'peace and stability' to Sudan. The actuality is that America has sowed instability first by physically violent covert global warring in Sudan; second by symbolically violent cherry picking of the grim fatalities in Darfur; and third by participating in a high-channel regime of bias that pushed peoples' perceptions towards judgments that Sudan's government was ghastly, like the Nazi's. This being the case, America is at least in some measure responsible for the horror in Darfur that it so loudly denounced, which means the Secretary of State's assertion that the US wanted 'peace and stability' for Sudan is hypocritical. It is time to draw the strings of this discussion and speak of the qualitative in the quantitative.

\section{Conclusion}

'All research ultimately has a qualitative grounding' (Miles \& Huberman, 1994: p. 40)

This article has introduced a strategy for the study of bias in social and cultural realms of quantitative assessment, and has applied it, among other places, to the disasters of war in Darfur. The strategy asks investigators identify the sources of bias, understood as forces pushing knowledge in particular directions. Researchers were also advised to explore two sorts of biasing sources, those having to do with epistemic and political forces; with the actual exercisers of force being different epistemic and political regimes. Three epistemic sources of bias were identified. The first was where epistemic regimes operated with imperfect techniques; the second was where they operated subject to imperfections of meaning resulting from cultural relativism; and the third was where they operated under limitations of emotive coloring. Two political sources of bias were distinguished. The first was direct, and occurred when political regimes themselves actually performed operations that resulted in biasing. The second source of political bias was indirect, and happened when resources flowed from political regimes to epistemic regimes in ways that influenced biasing. Two sorts of political/epistemic regime resource flows were discussed; those involving money and those involving intellectual resource flows. A goal, of the utilization of this strategy of bias assessment is

${ }^{7}$ The UN, EU, Canada, and England did not label Sudan a genocidal state. One reason for this is that the UN Genocide Convention, the legal basis for making rulings on genocide, insists that those committing it must intend to do so. The UN could not find intention on the part of the Sudanese government (Straus, 2005). American authorities were not interested in slippery subjectivities like intentionality; for them size mattered and the higher estimates provided just the right emotional jolt to shock people into believing that genocide had taken place. 
that if investigators can know the sources of bias, then they know what they have to eliminate, in order to achieve greater rigor in their assessments of approximate truth of actualities.

What is the relevance of this bias assessment strategy for consideration of the relationship of qualitative to quantitative inquiry? Quantitative information is that relating to, or expressible in, terms of quantities of reality. It is the different war fatality figures produced by the different epistemic regimes studying the Darfur conflict. Qualitative information is that relating to, or expressible in, terms of distinguishing features of reality, which in the case of humans pertains to the meanings they attach to things and the experiences they have of them. Of course, Donald Campell's claim, 'All research ultimately has a qualitative grounding', is correct in the sense that concepts seeking to know about how much of some being there is ultimately are, or depend on, concepts that specify that beings' distinguishing features. Otherwise put, quantitative concepts have distinguishing features, so that the qualitative is in the quantitative. Consider, for example, the earlier discussed Drawa-Person IQ Test. It was constructed without a thorough consideration of all the distinctive features of all the people to be subjected to it. Consequently, it did not discover that a taboo against drawing human figures was a distinguishing feature of Islam. Recall that a distinguishing feature of discussing life-span in Chad was that age was calculated in terms of the number of dry seasons one have lived through, so investigators simply could not query, 'How old are you?'

Qualitative bias assessment has the potential of providing three sorts of knowledge. The first is understanding of why a particular assessment doesn't work. Questions in surveys are basic components of most social or cultural quantitative assessments. Remember I found the question 'Have you had children', when posed to Barma women, did not provide accurate responses. This discovery was made as a result of qualitative inquiry into the meaning of childlessness (a great humiliation) and into the experience of women trying to answer the question (emotions of sadness and shame). Childless, then, among Barma had distinguishing features which explained what the question 'Have you had children' was almost unanswerable for those women without children. The second variety of knowledge that qualitative bias assessment can provide is that of, given some knowledge of the approximate truth of a situation, why there is some bias against that truth. Here the case of Darfur war fatalities is germaine. While it was, and is, not possible to arrive a particular figure for these deaths, the GAO report makes clear that the higher figures are improbable. However, the Bush II political regime opted, as we have seen, for the higher estimates. Qualitative analysis into this regime suggested that it sought power over the political regime in Khartoum, that to acquire this power is implemented a policy of first physical and then symbolic violence against the Sudanese government. Qualitative inquiry revealed the distinguishing feature of the US government animus against the Sudanese government-it wanted power over it and it was willing to bias the numbers to try and get it. Qualitative bias assessment can also lead to a third, moral type of knowledge.

There does not appear to be any universal moral system. However, most moralities of which I am familiar frown upon hypocrisy. Investigations into the sources of bias can have the ability to reveal the disjunction between what social actors say they are doing and the actuality of what they are doing and hypocrisy is saying one thing-I love you-and doing anothersleeping with your best friend. US officials say they are horrified by the 'genocide' in Darfur when they are in some measure part of the horror.

\section{References}

Ayer, A. J. (1968). The origins of pragmatism. London: Palgrave Macmillan.

Bacevitch, A. (2002). American empire: The realities and consequences of U.S. diplomacy. Cambridge, MA: Harvard University Press.

Bacevitch, A. (2005). The new American militarism: How Americans are seduced by war. Oxford: Oxford University Press.

BBC News (2004). Powell declares genocide in Sudan. URL (9 September 2004) http://news.bbc.co.uk/1/hi/3641820.stm.

Becker, H. (1996). The epistemology of qualitative research. In R. Jessor, A. Colby and R. Sweder (Eds.), Ethnography and human development: Context and meaning in social inquiry (pp. 53-71). Chicago, Illinois: University of Chicago Press.

Bennett-Jones, Owen. (2007). Iraqi deaths survey "was robust”. BBC News. URL (22 February 2010)

http://news.bbc.co.uk/2/hi/uk_news/politics/6495753.stm.

BLS. (2010). How the government measures unemployment. Bureau of Labor Statistics Washington, DC: Department of Labor.

Boggs, C. (2004). Imperial delusions: American militarism and endless war (Polemics). Lanham: Rowman and Littlefield Publishers.

Booker, S., \& Colgan, L. (2004). Genocide in Darfur. The Nation Magazine. URL (3 September 2010)

http://www.thenation.com/doc/20040712/booker

Bourdieu, P. (1989). Social space and symbolic power. Sociological Theory, 17, 14-25. doi:10.2307/202060

Bourdieu, P. (1991). Language and symbolic power. Cambridge: Polity Press.

Brown, D., \& Partlow, J. (2008). New estimate of violent deaths among Iraqis is lower. Washington Post. URL (10 January 2002) http://www.washingtonpost.com/wp-dyn/content/article/2008/01/09/ AR2008010902793.html.

Burnham, G., Lafta, R., Doocy, S., \& Roberts, L. (2006). Mortality after the 2003 invasion of Iraq: A cross-sectional cluster sample survey. The Lancet, 368, 1421-1428. doi:10.1016/S0140-6736(06)69491-9

Cherry, D. (2009). Ambassador rice lies about Darfur genocide. Executive Intelligence Review. URL (8 March 2010) http://www.larouchepub.com/other/2009/3613rice_lies_genocide.ht $\mathrm{ml}$.

Clinton, H. (2009). Remarks on the sudan strategy. Washington, DC: Department of State. URL (23 February 2010) http://www.state.gov/secretary/rm/2009a/10/130686.htm.

Creswell, J. W. (2003). Research design: Qualitative, quantitative, and mixed method approaches. Thousand Oaks, CA: Sage.

De Waal, A. (2007). Deaths in Darfur: Keeping ourselves honest. The Sudan Tribune. URL (6 March 2010) http://www.sudantribune.com/spip.php?article23328.

De Waal, A. (2009). Who are the Darfurians? Arab and African identities, violence, and external engagement. In S. Hassan and C. Ray, Darfur and the crisis of governance in Sudan: A critical reader (pp. 125-145). Ithaca, Cornel University Press.

Department of State. (2005). State Department's fact sheet, "Sudan death tolls in Darfur”. Washington, DC: US State Department.

Flint, J. (2009). Reports of oil in Darfur are exaggerated. Aletho News Archives. URL (21 November 2009)

http://blogs.ssrc.org/darfur/2009/08/07/reports-of-oil-in-darfur-are-ex aggerated/

Ferguson, N (2004). Colossus: The price of America's empire. New York: Penguin.

Foucault, M. (1980). Power/knowledge: Selected interviews and other writings, 1972-1977. New York: Pantheon.

GAO. (2006). Darfur crisis: Death estimates demonstrate severity of 
crisis, but their accuracy and credibility could be enhanced. Wasington, DC: General Accounting Office. URL (6 March 2010) http://www.gao.gov/new.items/d0724.pdf.

Guha-Sapir, D., Degomme, O., \& Phalen, M. (2005). Darfur: Counting the deaths (method1). Brussels: Centre for Research in the Epidemiology of Disasters.

Hagan, J., Rymond-Richmond, W., \& Parker, P. (2005). The criminology of genocide: The death and rape of Darfur. Criminology, 43, 525-561. doi:10.1111/j.0011-1348.2005.00016.x

Harvey, D. (2003). The new imperialism. Oxford: Oxford University Press.

Hassan, A. (2009). The rise and fall of the Sudan alliance forces (1). URL (21 November 2009)

http://blogs.ssrc.org/darfur/2009/10/08/the-rise-and-fall-of-the-sudan -alliance-forces-1/.

Hassan, S. (2009). Naming the conflict: Darfur and the crisis of governance in Sudan. In S. Hassan and C. Ray (Eds.), Darfur and the crisis of governance in Sudan: A critical reader (pp. 154-169). Ithaca: Cornell University Press.

Kuhn, T. (1961). The Function of measurement in modern physical science. In H. Woolf (Ed.), History of the meaning of measurement in the natural and social sciences (pp. 32-51). Indianapolis: IND: Bobbs-Merrill.

Lévi-Strauss, C. (1948). La vie familiale et sociale des indiens nambikwara. Journal de la Société des américanistes, 37, 1-132. doi:10.3406/jsa.1948.2366

Locke, J. (1998). Essay concerning human understanding. Harmondsworth: Penguin.

Mamdani, M. (2009). The politics of naming: Genocide, Civil War, insurgency. In S. Hassan and C. Ray (Eds), Darfur and the crisis of governance in Sudan: A critical reader (pp. 145-153). Ithaca: Cornell University Press.

Marcus, J. (2009). The support troops are getting flack. The Times Higher Education. URL (22 February 2010) http://www.wired.com/dangerroom/2008/06/pentagon-opens/

Martin, P. (2010). US military noose tightens on Afghanistan town. World Socialist Web Site. URL (23 February 2010) http://www.sott.net/articles/show/202853-US-military-noose-tightens -on-Afghanistan-town

Miles, M., \& Huberman, A. M. (1994). An expanded sourcebook: Qualitative data analysis. Thousand Oaks, CA: Sage.

MSNBC. (2008). Death toll of 200,000 disputed in Darfur. URL (2 March 2010) http://www.msnbc.msn.com/id/23848444/ns/world_news-africa/page/2/. Nabarro, D. (2004). Mortality projections for Darfur' briefing presented October 15, 2004. Geneva: World Health Organization. URL (9 March 2010)

http://www.who.int/mediacentre/news/briefings/2004/en.

Penitsch, R. (2010). Politics of identity and local conflict in Darfur. Schlainiger Arbeitspapiere für Friedensforschung, Abrüstung und nachhaltige Entwicklung.

Porter, T. (1996). Trust in numbers: The pursuit of objectivity in science and public life. Princeton, NJ: Princeton University Press.

Price, D. (2009). Human terrain systems, anthropologists and the war in Afghanistan. Counterpunch. URL (2 March 2010) http://www.counterpunch.org/price12012009.html.

Reeves, E. (2006). Quantifying genocide in Darfur: April 28, 2006 (Part 1). Sudanreeves.org. URL (9 March 2010) http://www.sudanreeves.org/Article102.html.

Reyna, S. (2005). American imperialism: The current runs swiftly. European Journal of Anthropology, 45, 129-51.

Reyna, S. (2009). Taking place: “New wars” versus global wars. Social Anthropologie Sociale, 17, 291-317. doi:10.1111/j.1469-8676.2009.00078.x

Reyna, S. (2010). Hard truths: Addressing a crisis in ethnography. In O. Zenker and K. Kumoll, Ed., Beyond writing culture: Current intersections of epistemologies and practices of representation. New York: Berghahn.

Save Darfur. (2010). What Has Happened in Darfur? URL (6 March 2010) http://www.savedarfur.org/pages/primer.

Scrimshaw, N. S., \& Gleason, G. R. (1992). Rapid assessment procedures-Qualitative methodologies for planning and evaluation of health related programmes. Boston, MA: International Nutrition Foundation for Developing Countries.

Straus, S. (2005). Darfur and the genocide debate. Foreign Affairs, 84, 123-133. doi: $10.2307 / 20034212$

Turse, N. (2010). The complex: How the military invades our everyday lives. New York: Metropolitan Books.

VandeHei, J. (2005). In Break with UN, Bush Calls Sudan Killings Genocide. Washington Post. URL (8 March 2010) http://www.washingtonpost.com/wp-dyn/content/article/2005/06/01/ AR2005060101725.html.

Winter, R. (2004). Humanitarian crisis in Sudan. Testimony. Washington, DC: US Senate Committee on Foreign Relations. URL (6 March 2010) http://www.usaid.gov/press/speeches/2004/ty040615_1.html. 